\author{
PRZEMYSŁAW PIOTR TOMCZYK
}

Katedra Geobotaniki i Ekologii Roślin Instytut Ekologii i Ochrony Srodowiska Wydział Biologii i Ochrony Środowiska Uniwersytet Łódzki

Banacha 12/16, 90-237 Łódź

E-mail: przemyslaw.tomczyk@biol.uni.lodz.pl

\title{
PROTOTAXITES - ZAGADKOWE ORGANIZMY KOPALNE
}

\section{WSTEP}

W historii Ziemi istniały okresy kiedy, ze względu na panujące na niej warunki, oblicze naszej planety znacząco różniło się od obecnego, np. Ziemia-Śnieżka (niemal cała planeta skuta lodem) (WALKER 2003) czy okresy ciepłego klimatu, kiedy w pobliżu bieguna południowego rosły ciepłolubne lasy (TOMCZYK 2016), lub ze względu na same formy istot żywych, zupełnie odmienne od współczesnych. $Z$ jedna $z$ takich sytuacji mieliśmy do czynienia $\mathrm{w}$ dewonie $(419,2-$ 358,9 mln lat temu), kiedy największymi przedstawicielami istot żywych na lądach były kilkumetrowej wysokości grzyby (prawdopodobnie grzyby zlichenizowane), o pokroju przypominajacym drzewa - organizmy $z$ rodzaju Prototaxites, a wszystkie żyjace wówczas rośliny rosły w ich cieniu - zasadniczo sytuacja odwrotna od obecnej (Ryc. 1). Przed bliższym opisem tych organizmów warto jednak przytoczyć historię ich odkrycia, równie interesujaca jak one same.

\section{PROBLEMATYCZNE ODKRYCIE}

Odkrywanie przedstawicieli Prototaxites dla nauki zaczęło się w 1843 r., kiedy to ich skamieniałości, razem ze szczątkami dewońskiej roślinności, zostały zebrane przez W. E. Logana na wybrzeżach Gaspé Bay (prowincja Quebec, Kanada). Pozostawały jednak niezbadane aż do 1855 r., kiedy to kolekcja trafiła do J. W. Dawsona (HUEBER 2001). Jego uwage przykuły od razu wielkie skamieniałości, zaskakujące jak na datowa- nie geologiczne skał $\mathrm{w}$ jakich zostały odnalezione (występujące wówczas rośliny lądowe były niewielkie) (SElosse 2002). Dawson stwierdził, że sa to prymitywni przedstawiciele drzew szpilkowych i stad nazwal je Prototaxites (łac. pra-cis). Trzynaście lat później Carruthers podważył stanowisko Dawsona; wg niego odnalezione szczattki były częśsia wielkiego glonu (HUEBER 2001), podobnego np. do występującej dzisiaj lesonii, brunatnicy o pokroju przypominającym palmę, występujacej w chłodniejszych, przybrzeżnych wodach półkuli południowej (PODBIELKOWSKI 1985) i zaproponował nazwę Nematophycus. Później sam Dawson wyparł się uznawania Prototaxites za iglaste i zaproponował nazwe Nematophyton uznajac, że były to glony. Odtad te 3 nazwy: Nematophyton, Nematophycus i Prototaxites funkcjonowały jako synonimy, ale $\mathrm{w}$ oficjalnej nomenklaturze uznaje się tylko ostatnia $z$ nich (HUEBer 2001) pomimo tego, że sama nazwa sugeruje fałszywe powiazania filogenetyczne; w nomenklaturze jest to jednak sytuacja normalna i nierzadko spotykana. Również budowa mikroskopowa skamieniałości Prototaxites nie mówi jednoznacznie, $z$ jakim organizmem mamy do czynienia - obserwuje się tutaj skomplikowany system włókien. Poczatkowo zostały one podzielone na 2 grupy. Większe, tzw. rurki (ang. tubes) maja od 20 do $50 \mu \mathrm{m}$ średnicy i ściany grubości 2,6 $\mu \mathrm{m}$. Biegna wzdłuż ciała organizmu, brak im przegród i nie sa rozgałęzione. Uważa się, że rurki mogły pełnić rolę usztywniająca i podporowa. Mniejsze, znacznie liczniejsze włókna maja 5-10 $\mu \mathrm{m}$ średnicy i bardzo obficie rozga- 
łęziają się, w głównej mierze budujac ciało Prototaxites (SELOSsE 2002). Później dokonano bardziej szczegółowego podziału. Część rurek dalej uważano za komórki podpierajace, jednak wydzielono jeszcze dodatkowe rodzaje filamentów: strzępki generatywne (do 50 um średnicy, podzielone częściowymi przegrodami), strzepki wiążące (najmniejsze, pozbawione przegród, niezespolone) i promienie rdzeniowe (nazwane tak przez podobieństwo do struktur anatomicznych roślin), widoczne na przekroju poprzecznym, jako promieniście rozchodzace się liniowe struktury, być może pełniące funkcję wydzielnicza) (SELOSSE 2002).

Oprócz uznawania skamieniałości Prototaxites jako iglastych czy glonów, rozważano także:

- ślepa uliczkę ewolucji lądowego życia, nie majacca obecnie żadnych żyjacych przedstawicieli;

- rodzaj organizmu symbiotycznego na kształt porostów (również składającego się $z$ grzyba i organizmu autotroficznego); grzyb;

- lądowy organizm saprofityczny, np.

- lub wg zupełnie odmiennej interpretacji - nie sa to stricte szczątki konkretnego organizmu, ale rodzaj artefaktu paleontologicznego, skamieniałe „zrolowane maty watrobowców" (ang. rolled liverwort mats) (HUEBER 2001).

Ostatnie dwie interpretacje były w ubiegłych latach przedmiotem burzliwej dyskusji naukowej.

\section{DEBATA: „ZROLOWANE MATY WATROBOWCOW" - OGROMNE GRZYBY}

Koncepcja interpretowania skamieniałości Prototaxites jako „zrolowanych mat watrobowców", podczas gdy inni badacze przypisywali je np. drzewom, może wydawać się zaskakująca. Kiedy jednak przyjrzymy się jej bliżej, przemawiaja za nia pewne interesujace argumenty. GRAHAM i współaut. (2010b), biorąc pod uwage pojawiające się $\mathrm{w}$ literaturze niejasności (i) w budowie anatomicznej: ogromne rozmiary organizmu, a ponadto brak śladów zarodników oraz brak podstawek (basidium) i wyraźnych przegród (sept) w obrazie mikroskopowym, których należałoby oczekiwać, gdyby to był owocnik grzyba (najprawdopodobniej podstawczaka), oraz (ii) odnośnie składu biochemicznego, czyli obecność pozostałości polimerów typowych dla roślin: ligniny, suberyny i kutyny), uznali, iż Prototaxites nie moga być grzybami, a sa częściowo zdegradowanymi matami niskiej roślinności, zrolowanymi w wyniku działania wody, wiatru lub grawitacji. Płaty takie zbu- dowane były wg autorów $\mathrm{z}$ miksotroficznych ${ }^{1}$ wątrobowców. Ryzoidy (odpowiedniki korzeni, m.in. u mszaków) wątrobowców oraz tubularne elementy budowy współżyjących $z$ nimi mikroorganizmów miały być odpowiedzialne za obserwowany w skamieniałościach Prototaxites system rurek. GRAHAM i współaut. (2010b) przeprowadzili nawet eksperyment, podczas którego symulowali powstanie „zrolowanej maty wątrobowców" (użyto w tym celu Marchantia polymorpha), uzyskując efekt, który według nich samych wyglądał podobnie, do tego jak wyglądaja skamieniałości Prototaxites. Publikacja GRAHAM i współaut. (2010b) spowodowała ożywiona reakcję środowiska naukowego. Wśród argumentów kwestionujących tę hipotezę należy wymienić następujące fakty (BOYCE i HOTTON 2010, TAYLOR i współaut. 2010):

1) większe rurkowate struktury, interpretowane jako ryzoidy, powinny być styczne do powierzchni maty watrobowców i prostopadłe do niej, w rzeczywistości w skamielinach sa one umieszczone równoległe;

2) przekrój przez zrolowana matę powinien wyglądać jak spirala, podczas gdy ma formę koncentrycznych okręgów, takich jak słoje przyrostu rocznego u drzew;

3) grubość poszczególnych warstw zrolowanej maty powinna być ograniczona grubościa pierwotnej, niezwiniętej maty. Grubość pierścieni w niektórych skamieniałościach Prototaxites jest bliska $2 \mathrm{~cm}$, prawie 10 razy więcej niż maty opisywane przez GRAHAM i współaut. (2010b), liczące 2,6 mm;

4) pomiędzy warstwami wattrobowców powinny znajdować się cząstki materii organicznej i gleby, czego jednak się nie obserwuje;

5) poszczególnych warstw zrolowanej maty nie powinny przenikać $\mathrm{w}$ zorganizowany, regularny sposób żadne inne struktury, natomiast zazwyczaj obserwuje się wymienione wcześniej promienie rdzeniowe nasuwajace skojarzenia $z$ promieniami drzewnymi w drewnie, co sugeruje, że mamy do czynienia $z$ tkankami jednego organizmu;

6) wg GRAHAM i współaut. (2010b), zawartość stabilnych izotopów węgla uzyskanych podczas ich eksperymentu, zgadzała się $z$ wartosciami uzyskiwanymi przez różnych autorów ze skamieniałości Prototaxites. Przy głębszych analizach okazuje się jednak, że zgodność ta jest iluzoryczna - biorąc pod uwage różnice $\mathrm{w}$ wartościach $\delta^{13} \mathrm{C}$ dla powietrza $\mathrm{w}$ dewonie $\mathrm{i}$ współcześnie $\left[\delta^{13} \mathrm{C}\right.$ to zawartość izotopu węgla ${ }^{13} \mathrm{C}$ wyrażona w cząstkach na $1000(\% o)]$;

${ }^{1}$ miksotroficznych, tzn. zdolnych do odżywiania się w sposób samo- lub cudzożywny w zależności od warunków środowiska; taką zdolność mają np. żyjące współcześnie wątrobowce $z$ rodzaju Marchantia, a wynika ona ze związków z grzybami i cyjanobakteriami. 


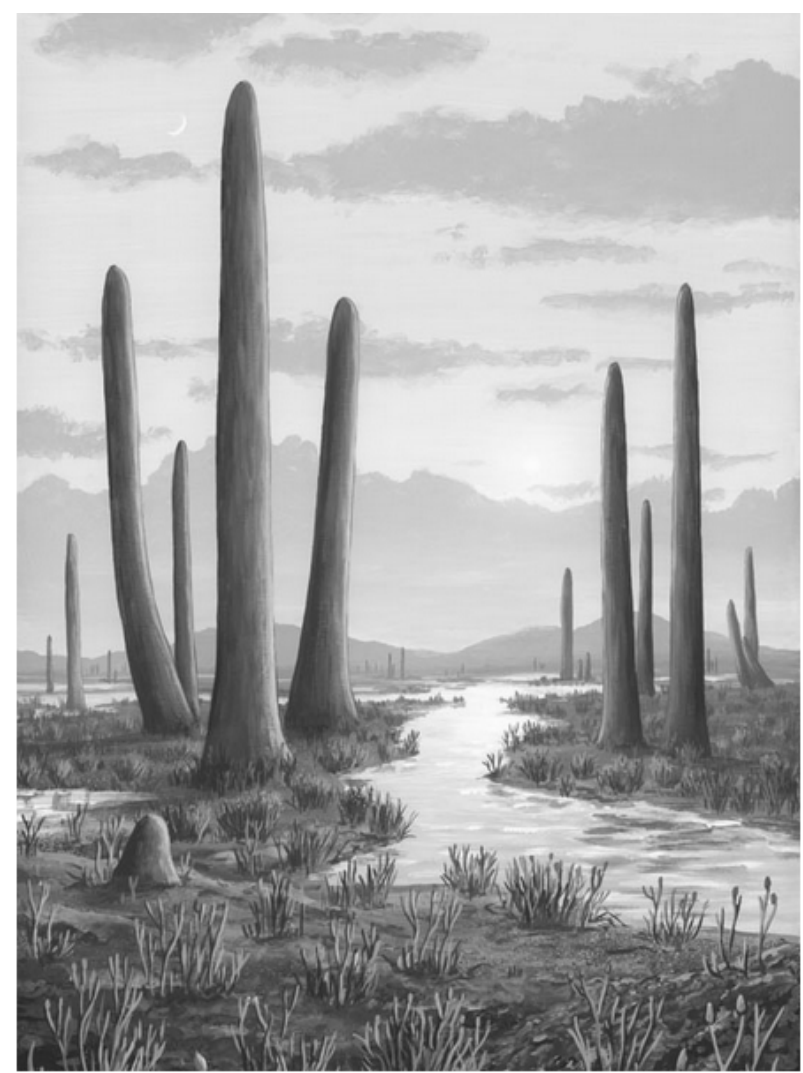

Ryc. 1. Artystyczna wizja dewońskiego życia na lądach.

Pośród rozlewisk rosna prymitywne, niskie rośliny oraz dominujace nad krajobrazem Prototaxites - przedstawione w formie kolumnowej. Obecnie uważa się jednak, że w szczytowej części mogły być lekko rozgałęzione (grafika dzięki uprzejmości Richarda Bizleya; http://www. bizleyart.com).

7) bardzo mało prawdopodobne jest naturalne powstanie tak wielkich i jednocześnie regularnych rulonów.

Obecnie koncepcja zrolowanych mat wątrobowców jako interpretacja skamieniałości Prototaxites nie jest uznawana za wiodąca, a jej autorzy zgodzili się $z$ większością krytycznych uwag. Pozostawili jednak jako otwarte pytanie, dlaczego $\mathrm{w}$ zapisie kopalnym nie obserwuje się takich struktur. W dewonie, wobec relatywnego braku konkurencji ze strony roślin naczyniowych oraz właściwości samych watrobowców: efektywnego rozmnażania płciowego i bezpłciowego czy dużej odporności na warunki stresowe w środowisku, należałoby oczekiwać, że były niezwykle rozprzestrzenione na lądach, przed pojawieniem się roślin naczyniowych i podczas ich wkraczania na lądy. W takich warunkach maty watrobowców pod wpływem licznych czynników fizycznych mogłyby miejscami odrywać się od podłoża i rolować, pozostawiając w zapisie kopalnym ślady, jeśli nieidentyczne jak skamieniałości Prototaxites, to przynajmniej podobne do nich (GRAHAM i współaut. 2010a).

\section{DALSZE ARGUMENTY ZA UZNANIEM PROTOTAXITES ZA GRZYBY}

Wkrótce opublikowane zostały kolejne badania, sugerujace przynależność Prototaxites do grzybów, m.in. doświadczenia przeprowadzone w Górach Kaskadowych w stanie Waszyngton (USA) (HoBBIE i Boyce 2010). Przedmiotem zainteresowania badaczy było specyficzne miejsce: płytkie zbiorniki wodne powstające u czoła lodowca górskiego i ich sąsiedztwo, słabo skolonizowane przez rośliny wyższe. Siedliska takie (rozlewiska z rzadkimi i rozerwanymi płatami roślinności) uznano za analogiczne do panujących w późnym sylurze i w dewonie. Dodatkowym argumentem był fakt, iż gleba pobrana $z$ krawędzi takich basenów wykazywała wyższe wartości $\delta^{13} \mathrm{C}$ niż gleba $z$ sasiednich terenów, gdzie występowały rośliny. Różnica ta wynikała prawdopodobnie stą, że na krawędziach zbiorników dominującym producentem materii organicznej sa mikroorganizmy, a dalej - rośliny. Rosnący na takich terenach saprotroficzny grzyb Arrhenia obscurata wykazywał duże zróżnicowanie izotopów węgla w swoich tkankach i podwyższony poziom węgla ${ }^{13} \mathrm{C}$, nieprzystający do zawartości izotopów węgla u współwystępujących roślin wyższych - analogicznie jak Prototaxites. Tłumaczyłoby to, skąd w ich skamieniałościach spotyka się taki profil izotopów węgla. Jeśli organizmy te żyły na rozlewiskach, gdzie głównym źródłem materii organicznej były osady powstale $z$ glonów, a same organizmy były grzybami i odżywiały się saprotroficznie wymienionymi osadami, specyficzne proporcje izotopów węgla w ich ciałach staja się wytłumaczalne, co potwierdzaja badania nad współczesnymi grzybami rosnacymi w podobnych warunkach (HOBBIE i BOYCE 2010).

Nowe światło na przynależność taksonomiczna Prototaxites przyniosły także wykopaliska $z$ dolnodewońskich osadów na terenie pogranicza walijsko-angielskiego (EDWARDS $i$ AXE 2011). Opisano stamtąd nowe osobniki $\mathrm{z}$ gatunku Nematasketum diversiforme, uznawanego za blisko spokrewnionego $z$ przedstawicielami rodzaju Prototaxites. Odkryte skamieniałości były pierwszymi, na których wyraźnie widać, że tego typu organizmy miały przynajmniej w części osiowa organizacje ciała $z$ obwodowa częścia formująca rodzaj skórki. Analizy morfologiczne wskazały, że w sposób oczywisty nie mamy tutaj do czynienia ze zrolowanymi matami watrobowców, ciało organizmu zbudowane było $z$ liniowych struktur przypominających 
mycelium grzybów. Wyniki z 2014 r. przyniosły kolejne przesłanki przemawiajace za pokrewieństwem Prototaxites $z$ grzybami (RETALLACK i LANDING 2014). Poszlak dostarczyły badania nad słynnym okazem skamieniałego Prototaxites loganii: „Schunnemunk tree”. Obraz histologiczny wskazuje na przynależność wymarłego taksonu do grzybów: gromady Glomeromycota (tzw. „kłębiankowców”) lub podgromady Mucoromycotina. Podano w wątpliwość przyjmowana przynależność Prototaxites do gromady Basidiomycota (podstawczaki) ze względu na brak wyraźnych cech grzybni dikariotycznej. Badania te jednocześnie przyniosły ważne poszlaki sugerujace, że Prototaxites nie były stricte grzybami.

\section{OBECNA INTERPRETACJA}

Obecnie uznajemy, że Prototaxites były przynajmniej w większej części grzybami. Jednak liczne przesłanki wskazuja, że ich natura była bardziej złożona: prawdopodobnie były organizmami symbiotycznymi, na kształt porostów (RETALLACK i LANDING 2014). Glony miałyby zasiedlać zewnętrzna powierzchnię ciała grzybni. W miare wzrostu organizmu na grubość, warstwa glonów położona głębiej obumierała (przez stopniowe odcięcie dostępu do światła), dając jednocześnie poczatek nowej powierzchniowej warstwie. Wskazuja na to właśnie badania RETALLACKA i LANDINGA (2014). Najbardziej zewnętrzna część pnia posiadała słabo zachowane inwaginacje, powyżej korowych gniazd komórek kokoidalnych (interpretowanych jako komórki glonu) obejmowanych przez silnie rozgałęzione, rurkowate komórki (strzępki grzyba) - jest to budowa mikroskopowa charakterystyczna dla porostow. Prototaxites wymarły w przybliżeniu wtedy, gdy pojawiły się rośliny drzewiaste i krzewiaste. Wcześniej (400-350 mln lat temu) były one największymi organizmami lądowymi (osiągajacymi nawet $8 \mathrm{~m}$ wysokości i $1 \mathrm{~m}$ średnicy), rosły na całym świecie, pośród nielicznych, prymitywnych, niskich roślin, takich jak psylofity (np. Aglaophyton major). Prototaxites posiadały powiększona część przyziemna, co sugeruje połączenie $z$ częściami podziemnymi, służącymi do rozkładania martwej materii organicznej (SELOSSE 2002). Źródłem tej materii prawdopodobnie tylko w mniejszej części były rośliny wyższe, główny składnik mogły stanowić szczatki drobnych organizmów glebowych oraz tych, żyjacych w płytkich wodach i rozlewiskach: glonów, bakterii i grzybów (BOYCE i współaut. 2007, HoBBIE i BOYCE 2010). Sugeruje to wspominana wcześniej znacząca różnica w zawartościach izotopów węgla, w porównaniu do współwystępujacych w środowisku roślin telomowych.

Nadziemne części Prototaxites mogły pojawiać się tylko okazjonalnie (HUEBER 2001), zastanawia jednak fakt, dlaczego były aż tak wielkie. Mogła być to część organizmu odpowiedzialna za fotosyntezę. Tłumaczyłoby to jej rozmiary i wzniesiona, kolumnowa formę, co pozwalałoby na większy dostęp do światła. Biorac pod uwage wymarcie Prototaxites podczas rozkwitu roślin drzewiastych, nasuwa się myśl, że powodem tej zagłady była konkurencja ze strony znacznie lepiej przystosowanych organizmów samożywnych (SELOSSE 2002).

Jako jeden $z$ powodów wymarcia Prototaxites rozważano wcześniej działalność stawonogów drążacych ich pnie, co widać w zapisie kopalnym, jednak $z$ tym problemem musiały mierzyć się już od wczesnego dewonu (najwcześniejsze znaleziska), a więc od początku swojego istnienia, nie mógł to więc być główny powód ich wymarcia (LABANDEIRA 2007). Nie wiadomo do tej pory, w jaki sposób Prototaxites rosły (sposób ich wzrostu wydaje się nieciagły) (SELOSSE 2002) ani jak się rozmnażały (TAYLOR i współaut. 2010), nigdy bowiem nie odnaleziono zarodników, ani podobnych struktur. Jeżeli organizmy te były podobne do porostów, mogły rozmnażać się przez fragmentację plechy lub lichenizację (w wyniku bezpośredniego kontaktu odpowiedniego grzyba i glonu). Dotychczasowy duży postęp w badaniach nad Prototaxites daje jednak nadzieję, że w przyszłości nasza wiedza na ich temat będzie coraz pełniejsza.

$$
\text { Streszczenie }
$$

Prototaxites to wymarły rodzaj organizmów żywych; występowały one na całym świecie od późnego syluru do późnego dewonu (420-370 mln lat temu). Wymarły jednocześnie $z$ rozwojem roślin krzewiastych i drzewiastych. Miały cylindryczna, wzniesiona formę, przypominająca kolumnę o wymiarach nawet $8 \mathrm{~m}$ wysokości i 1 $\mathrm{m}$ szerokości, $z$ pojedynczymi, krótkimi rozgałęzieniami w szczytowej części. W ciąu wieków kwestia interpretacji ich skamieniałości była przedmiotem ożywionej debaty naukowej. Obecnie uważa się, że najprawdopodobniej były organizmami symbiotycznymi, związkiem grzyba i glonu.

\section{LITERATURA}

Boyce C. K., HotTon C. L., 2010. Prototaxites was not a taphonomic artifact. Am. J. Bot. 97, 1073.

Boyce C. K., Hotton C. L., Fogel M. L., Cody G. D., HAZEN R. M., KNoll A. H.,. Hueber F. M., 2007. Devonian landscape heterogeneity recorded by a giant fungus. Geology 35, 399402.

EDWARDS D., AXE L., 2011. Evidence for a fungal affinity for Nematasketum, a close ally of Prototaxites. Bot. J. Linnean Soc. 168, 1-18.

Graham L. E., COOK M. E., HANSON D. T., PIGG K. B., GRAHAM J. M., 2010a. Rolled liver- 
wort mats explain major Prototaxites features: Response to commentaries. Am. J. Bot. 97, 1079-1086.

Graham L. E., Cook M. E., Hanson D. T., Pigg K. B., Graham J. M., 2010b. Structural, physiological, and stable carbon isotopic evidence that the enigmatic Paleozoic fossil Prototaxites formed from rolled liverwort mats. Am. J. Bot. 97, 268-275.

HobBie E. A., Boyce C. K., 2010. Carbon sources for the Palaeozoic giant fungus Prototaxites inferred from modern analogues. Proc. Royal Soc. B, doi: 10.1098/rspb.2010.0201.

HUEBer F. M., 2001. Rotted wood-alga-fungus: the history and life of Prototaxites Dawson 1859. Rev. Palaeobot. Palynol. 116, 123-158.

LABANDEIRA C., 2007. The origin of herbivory on land: Initial patterns of plant tissue consumption by arthropods. Insect Sci. 14, 259-275.

PODBIELKOWSKI Z., 1985. Glony. Wydawnictwa Szkolne i Pedagogiczne, Warszawa.
Retallack G. J., LANDing E., 2014. Affinities and architecture of Devonian trunks of Prototaxites loganii. Mycologia 106, 1143-1158.

Selosse M.-A., 2002. Prototaxites: A 400 Myr old giant fossil, a saprophytic holobasidiomycete, or a lichen? Mycol. Res. 106, 641-644.

TAYLOR T. N., TAYLOR E. L., DECOMBEIX A.-L., SchwendemanN A., SERBET R., Escapa I., KRINGS M., 2010. The enigmatic Devonian fossil Prototaxites is not a rolled-up liverwort mat: Comment on the paper by Graham et al. (AJB 97: 268-275). Am. J. Bot. 97, 1074-1078.

TOMCZYK P. P., 2016. Zielona Antarktyda - zmiany klimatu $i$ szaty roślinnej Antarktydy podczas kredy $i$ kenozoiku. Wszechświat 117 , 209-214.

WALKER G., 2003. Snowball Earth. Bloomsbury Publishing, Londyn.

KOSMOS Vol. 67, 2, 251-255, 2018

PRZEMYSEAW PIOTR TOMCZYK

Department of Geobotany and Plant Ecology, Institute of Ecology and Environmental Protection, Faculty of Biology and Environmental Protection, University of Łódź,

12/16 Banacha Str., 90-237 Łódź, E-mail: przemyslaw.tomczyk@biol.uni.lodz.pl

PROTOTAXITES - THE ENIGMATIC FOSSIL ORGANISMS

Summary

Prototaxites are an extinct genus of living organisms, the representatives of which occurred all over the world from the Late Silurian to Late Devonian Period (420-370 million years ago). They became extinct with the development of shrubby and woody plants. They had cylindrical, upright form, resembling a column up to $8 \mathrm{~m}$ in height and $1 \mathrm{~m}$ in width with single, short branches in the top part. Over the centuries, the question of interpretation of their fossils was the subject of intense scientific debate. Currently, it is considered that most likely they were symbiotic organisms, which consisted of a fungus and an alga.

Key words: Devonian, fossils, fungi, lichens, paleobiology, plant cover 